\title{
Elements of Machiavenialism and Situationism in William Golding's Lord of the Flies
}

Oyenuga, Olukayode, Felix *

\begin{abstract}
This essay examines the nature of man within the scope of situational philosophy. It explores the writing of William Golding to subvert intellectual error on racism. Besides, it challenges any claim to absolute moral refinement since existential situation set the stage for the unfolding of man. The radical transformation of Jack Merridew and the situational response of Ralph are used as philosophical base to explain the dynamism of man in the face of changing situation. However, the analysis of some scholars on the black race reveals a fundamental philosophy that misses many fundamental points. This paper therefore advocates an incursion into appropriate political framework and dismissal of race based supremacist philosophy.
\end{abstract}

\section{Introduction}

Philosophy, jurisprudence and other disciplines in the humanities are loaded with principles for interpreting human conduct in the midst of competing choices. Deontological and teleontological theories have been proposed and reformulated to gain a better

* Department of Philosophy, Faculty of Arts, Olabisi Onabanjo University, Nigeria;kayodeoyenuga@yahoo.com 
understanding of the phenomena. However, apart from philosophical expositions on these theories, there are literary expressions which include philosophical dimensions of text that offers deeper insight into such theories when properly examined and analysed. Lord of the Flies by William Golding is a text that deserves mention. This text underscores the fact that man is an ambivalent being, best understood from a multi-causal interpretative perspective. He/She is not amenable to a fixed mathematical interpretation but is situationally directed in the quest for survival. Thus, the worst act can be the best as situation warrants.

This paper will critically explore the character of Jack in Golding's Lord of the Flies through a Machiavellian and situationist perspective. The two theories are of fundamental essence in the development of his character. Besides, it will also be argued that there is a 'Jack' like character in every man and the behavioral and ideological characteristics of Jack can be expressed depending on specific situational necessity and contextual relevance.

\section{Man and Ethical Theories}

The working or effectiveness of any idea is predicated on an individual. Thus, a wrong interpretation of the nature and essence of an individual will vitiate the working of institution, idea and organisation. Ordinarily, ideas and action plans are crucial components of institutional mission, but as crucial as they may be, the most crucial factor is the individual him/herself. The workability or failure of idea is ultimately predicated on individuals as a foundational and rational factor in the midst of other factors. Thus, an apt understanding of an individual is important for proper placement, review and assessment of the bane and the prospects of human institution. Indeed, scholarship is awashed with theories on human nature, tendencies and possibilities. In the midst of these theories, we are of the view that an individual is best understood situationally. Especially, the complex unfolding of human nature in contemporary time makes recourse to situationism inevitable. Marx Maslow substantiates such an argument in the following manner 


\begin{abstract}
"The corpus of literature on human nature is still unfolding.... Indeed, contemporary findings and actions as exhibited in gay marriage, bestial marriage etc. have shown that man is ever becoming in existential term. His potential and possibilities are inexhaustible. He is dynamic, rational and not amenable to linear mathematical analysis" (2012, p.14)
\end{abstract}

In line with Marslow's view, if an individual is really dynamic, then only a dynamic ethical theory can capture the nature and tendencies of him/herself. Ethical theory as mentioned here "emphasizes or explains on various aspects of an ethical dilemma and gives directions to the generally and ethically acceptable decision based on well-established criteria" (Richard, 2012, p.18). In other words, these theories enshrine fundamental principles for analysing human conduct. Some of these are observed below:

Teleological Theory: Teleological theory judges the rightness of an action in terms of an external goal or purpose. Hence, 'consequence' inevitably plays an important part in the determination of what is normally allowed or morally disallowed. Meanwhile it will be wrong to regard all teleological theories as consequentialist. John Rawls theory of justice is teleological but not consequentialist. This is because Rawls is of the view that consequences are only part of what must be considered when determining what policy is morally just (Rawls, 1972, p. 74). Omoregbe (1998, p. 267) observes that Rawls seems to reject "the utilitarian principle of social justice-the greatest happiness of the greatest number- according to which a society is said to be just and well ordered".

John Stuart Mill, in his utilitarianism, offers a clear insight into utilitarianism. He writes:

"The creed which accepts as the foundation of morals utility or the greatest happiness principle holds that actions are right in proportion as they tend to promote happiness, wrong as they tend to promote happiness, wrong as they tend to produce the reverse of happiness. By happiness is intended 
pleasure and the absence of pain; by unhappiness pain and the privation of pleasure" (Mill 1972, pp. 910).

J.S Mill further argues that the happiness which forms the utilitarian standard of what is right in conduct is not the agent's own happiness but that of all concerned as between his own happiness and that of the others, utilitarianism requires him to be strictly impartial as a disinterested and benevolent spectator (Mill, ibid).

Actually, the consequential effect of pleasure in bringing about the 'summon bonum' is good but defective. The utilitarian confuse pleasure with happiness. Pleasure and happiness are not synonymous as the utilitarians assume. Omoregbe (1998, p. 238) asserts that "pleasure does not always bring happiness. In fact, some pleasures bring unhappiness. Not all pleasures are good". The most serious flaws in the utilitarian theory is that it implies that the end justifies the means. "If all that count about the morality of an action is the result, then one could employ an evil means to bring out a good result". (Ibid)

In simple terms, the utilitarians argue that utility is the moral standard. It is the parameter with which the property of action is considered. Those actions which tend to produce pleasure are good while those that promote unhappiness are bad.

Deontological Theory: Deontological theories reject what teleological theories affirm. Frankena (1995, p. 15) observes that utilitarians "deny that the right, the obligatory and the normally good are obligatory; whether directly or indirectly". Demotologists firmly believe that there are other considerations that may make an action or rule right or obligatory besides the goodness or otherwise of its consequences. This principle is expressly manifested in Kant's ethical theory, especially the postulation of categorical imperative. Kant (1985, p. 54) observes that "categorical imperative is an unconditional imperative and it holds necessarily, universally and unconditionally for all. It concerns not the material of the action and its intended result but the form and the principles from which it results". Karl H Peschke (2001, p. 34) further explains the abovementioned statement by stating that the "moral obligation 
must be fulfilled for its own sake, not for the hope of happiness since this would be a mercenary ethics founded on pleasure or utility: not for the sake of God as lawgiver and final goal".

In all, Immanuel Kant enjoins us to act in such a way that the underlying ethics or principles of our acts can be commuted and accepted as a universal law. This is a plausible and person oriented principle but it is not beyond criticism. There are several morally good acts which may not become a universal law.

\section{Situation Ethics and Machiavllianism}

Situation ethics is also known as the New Morality. It focuses on the expediency of situation. As an ethical theory, situationism emphasises situation as the determining factor in the morality of any action. Every situation is unique. Thus, a critical appraisal of the situational influence behind an action is inevitable in the assessment of an action as right or wrong. According to Omoregbe (1998), "situation ethics is largely a reaction against legalistic tendencies in ethics, especially in the Christian ethics which maintains that certain actions are intrinsically evil" (p. 254). Situationism advances that an action which is bad in situation ' $A$ ' may be perfectly good in situation $B$ as goodness and badness are not intrinsic properties of any action.

Basically, situationism as advanced by Joseph Fletcher accepts that situational appraisals could be universal moral principles. But it sees these principles only as guides in the making of decision and not as rigid, absolute and sacrosanct pronouncements. All moral norms are relative. There is no absolute moral norm, because no moral law is always applicable in all situations save the law of love. Love is the only absolute law. However, the working of this law must be done in such a way as to bring justice.

It must be noted that situationist ethics is pragmatic. It works on the premise as Onigbinde (1996, p. 58) who asserts, that "the validity of an idea is based on its workability and that idea is valid if it works". It rejects unrealistic principles, espouses the feasible ones and insists on the beneficial consequences of action. It must be noted that situationism is also relativistic. The propriety of action is relative to the nature of a given situation because no human action is intrinsically evil. 
It is worthwhile to state that situationism is an aspect of positivistic ethics. It abhors foundational metaphysics. It is a posteriori, not a priori. It embraces the empirical approach to moral decision making. Above all, the theory sees morality as constructive saying that morality must enhance the well-being and development of an individual because the individual is more important than moral principles.

It must be properly considered that situationism proposes that morality has situational elements of historical, cultural, social and many other variables. In line with this, it is expedient to gather relevant data, recognize fact and embark on empirical research before making a moral decision. This is simply because different situation may require different logic or ethical principles.

One prominent current in situationism is the tilt towards Machiavellianism, especially in the context of politics. "Machiavellianism" according to the Oxford English Dictionary (2005) "is the employment of cunning and duplicity in statescraft or in general conduct". It became popular as a term in the late $16^{\text {th }}$ century in England and highly popularized with the publication of The Principatibus (The prince). Nicollo Machiavelli advanced a radical severance of morality from political consideration. To him acquisition and retention of power are the fundamental goals of politics as the end justifies the means. Thus, do whatever you can do to acquire power. Nothing is too expensive to be done for power and in power.

The Prince (1974), a text written by Machiavelli Nicollo is an extended analysis of how to acquire and maintain political power. In the text, Machiavelli recommends the ideal behavioural pattern for princes. According to him the basic tenets of a prince entails the following: It is better to be stingy than generous, to be cruel than merciful, to break promises, if keeping them would be against one's interest. Princes must avoid making themselves hated and despised; the goodwill of the people is a better defence than any fortress. The text further recommends that a prince should choose wise advisors and avoid flatterers. 


\section{Lord of the Flies: A Synopsis}

Lord of the Flies is a literary expression of the manifestation of man within the context of order, disorderliness and social exigencies. The text was written by William Golding against the backdrop of the Second World War. Being a professional naval officer, having experienced the sorrow, the horror and the pain of war, translated his experience into readable form for serious didactic importance.

In the text, some boys were marooned on an uninhabited island when their plane crash landed. The boys realised that no adult seemed to have survived the crash to provide leadership. No father, no mother, no guardian. Luckily, Ralph and Piggy, two of the marooned boys, moved around the lagoon front while Piggy emphasized the need to look for the other boys. In the course of this exploration, Ralph came across an object which Piggy described as a conch. Piggy taught Ralph how to blow the conch. Ralph blew it and the noise from this serve as a herald which attracted the other marooned boys. With a view to establishing a semblance of the human society, there was an election where Ralph emerged the overall leader of the boys. Meanwhile, Jack emerged as an antagonist.

Throughout the novel, Jack hunted for an unidentified beast which he believed was a murderous being. The rulership of the island eventually degenerated into a crazy pursuit of power and display of animalistic disposition. In view of this, Simon died; Piggy was killed as well. His spectacle and head were broken, marking the beginning of anarchy on the island. In sheer desperation for power, Jack tried to kill Ralph. Jack and his boys set fire to force out Ralph out of his hiding place but the smoke attracted a British Naval Ship to the island and the naval officer put an end to the bestial decline of morality.

\section{Lord of the Flies: a Situationist Perspective}

Lord of the Flies is a literary masterpiece that showcases the reaction of an individual to a situation based on a prevailing condition. At the outset, there is a semblance of orderliness in the way the boys conducted their affairs but when the tussle for power set in, things fell apart. Fundamentally, Jack at the initial point could not cut though a living flesh or kill an animal because of the dignity or 
sanctity of human lives. In Golding's expression, "they knew very well why he hadn't killed the piglet because of the enormity of the knife descending and cutting, into living flesh because of the unbearable blood" (Golding, 1954, p. 31). At this point, one can rightly infer that Jack is a deomotologist. He is so human that he couldn't kill an animal and he tends to be teaching the other boys this principle on the sanctity of human life.

Initially, Jack retains the sense of moral rectitude that the society imparted into him but suddenly there was a descent to savagery. He soon became obsessed with hunting and devoted himself to the task of painting his face like a barbarian and giving himself over to bloodlust. He embraced savagery and violence of unimaginable proportion to achieve his goal. There was the conflict between two competing tendencies in him, between the norms of civilization and savagery, orders and chaos and law versus anarchy. This competing tendency is apparent in Golding's description of him

"He's tall, thin and bony: and his hair was red
beneath the black cap. His face was crumpled and
freckled and ugly without silliness. Out of this face
stared two light blue eyes, frustrated now and
turning or ready to turn to anger" (Golding, 1954,
p.1).

Jack really understands the language of power. Having been defeated by Ralph on the race for the rulership of the island, the earlier humane Jack became weird and desperate. He led the brutal slaughter of a pig and then Simon. He ordered his boys to beat up Wilfred for some unspecified misdeed. He threw his fear at Ralph with full intention" (Ibid., p.11). Most of the evil that befell the children on the island were his handiwork. He is an anarchist and a murderer. Though they unanimously agreed that the conch is a symbol of authority but when the desperate quest for power started boiling in him, he said: "the conch does not count on top of mountain" (ibid., p. 54).

A fundamental appraisal of Jack's character revealed a Machiavellian situationist. He believed in the acquisition and retention of power through any means, even with human blood as collateral. His motto ought to be power is good irrespective of how 
it is acquired. Machiavelli advised that the basic thing in politics was to try to grab power by all means, fair or foul and any means to retain it. Morality must be chequered from politics. He writes:

\begin{abstract}
"A prince therefore who desires to maintain himself must learn not to be always good but to be so or not as necessity may require... it is well that when the act accuses him, the result should excuse him and when the result is good, it will always absolve him from blame ... for all things considered, it will be found that some things that seem like virtue will lead you to vain, if you follow them; while others that apparently are vices, will, if followed, result in your safety and well-being" (Nicollo, 1974, ch.15).
\end{abstract}

The above quotation served as one of the ideological underpinnings of Jack's life. When the pursuit of power came to the fore, Jack became ruthless. Through his ruthlessness, certain key figures in the novel were eliminated. That was an evident warrant to his final coronation on the island as a generalising Simon, as an embodiment of morality and a pure spiritual essence. The discoverer of the alleged beast was murdered in cold blood. Piggy, the symbol of intellectual growth and voice of reason was also brutally murdered. Towards the end of the novel, his glasses were smashed by Jack and his group. Roger dislodges a rock from the mountain top which killed Piggy. His death was symbolic. It represents the annihilation of progressive, scientific and intellectual knowledge.

Of course, the death of Piggy cannot be adequately explained without recourse to Jack. Jack and his tribe of hunters ransacked Ralph's camp and made away with Piggy's spectacle. Piggy and Ralph made spirited effort to get the spectacles back. It was in the course of this that Roger released a huge rock which was directly located on the pathway occupied by Ralph and Piggy. It landed on Piggy's head. His head was shattered and the conch (symbol of authority) was equally shattered. Suddenly, Jack attacked Ralph with spear.

Philosophically, Machiavelli advanced that a Prince must surround himself with soldiers. Jack in conformity with this, trained his 
hunters in offensive and defensive art. Ralph lends credence to this when he described Roger as the one who "carried death in his hand" (p. 241). The likes of Roger and Maurice as instruments will, to a considerable extent, inculcate fear in the mind of the other boys on the island. Fear is necessary to keep people in perpetual servitude. When you create an atmosphere of fear, real or imagined, your followers will obey you easily. Ralph discountenanced the idea of Beast on the Island while Simon as a form of Philosophical exploration traced the whole thing to human act and nature, yet Jack insisted on a hurting expedition to track down the beast.

Machiavelli advised that it is better to be feared than to be loved. Being loved consistently by others is very risky. Hence, one should rely on fear that one creates in the mind of others; meanwhile, care should be taken that fear is not taken to the extent of being hated as it will produce just the opposite. If you cannot win love, avoid the hatred. Jack believed in this principle. He is ruthless no doubt but whenever he killed any game his boys enjoyed the meat. Though he, at a point maltreated Sam and Eric but the duo eventually believed in Jack having been lured by offering of meat. Act as a fox and a lion is another Machiavellian dictum. Jack is versed in this. He is cunning and bold. He ensured the shattering of the conch, used meat to lure the boys and like a savage tried to kill or wipe out perceived opponent. Another vital aspect of Machiavellianism is "Be extreme towards a friend or enemy". Do everything to help a friend. On the contrary, destroy the enemy before he gains root of power. Ralph tends to be a good counsellor and Piggy tends to be a good adviser but since the existence of the duo will spell doom for the political ambition of Jack, then the best option is to eliminate them. Piggy was killed but the attempt to kill Ralph was aborted. He set the entire island ablaze to kill one enemy i.e. Ralph.

Machiavelli suggests that a prince must always pay close attention to military affairs if he wants to succeed and remain in power. Jack absolutely complied with this norm. It is better to break promises if keeping them would be against one's interest. When Jack discovered the limitations posed by the law and the conch, then he became an iconoclast. He made it clear that he was not bound by any of the laws made by Ralph. 
A prince or ruler must choose or undertake great projects to enhance their reputation. Jack endeavoured to track down a nonexisting beast and believed in great hunting expedition and brave act to the amazement of the boys. He believed that moral principles must yield to the dictates of pure expediency and peculiarities of situation. Jack believed that leaders must cover their real intention, frequently act against mercy and religion in order to preserve the state.

Without delving into much verbiage, Lord of the Flies shows an individual as an amalgam of good and evil but the aspect that comes to the fore will be determined by situation. No man is a total saint and no man is a complete devil. Jack the good hunter is also Jack the great killer. He transformed the chair into hunters and through them he was able to carve out an area of influence for himself and a formidable force to outwit Ralph on the island. When we focus on his erstwhile humane disposition and the sudden metamorphosis, one cannot but unravel the expediency of situation as one of the causal factors.

\section{Conclusion}

Man is neither a complete beast nor a total angel. He is driven by situation and circumstances which in most cases determine his course of action. Jack carefully exemplifies this proposition dangling between the good and the bad as situation dictates. An analysis of his character shows that there is no saint in the context of power relation and whatever one can utilize to get power is a justifiable collateral, irrespective of the cost. Any human will utilize the pseudo-legitimate strategies that maximally contributes to whatever can further his/her interest. Meanwhile any institution or idea that tends to silence him/her by law is thrown down or reviewed.

\section{References}

Bentham, J. (1972). Introduction to the Principles of Moral Legislation. London: Oxford University Press. 
Etim, I. (1998). Ethics and the Politics of Self Perpetuation. In E. Bassely (ed.), Journal of Politics and Development. Uyo: Muller Publishers.

Fletcher, J. (1966). Situation Ethics. London: SCM.

Frankena, W. (1995). Ethics. Englewood Cliff: Prentice Hall Inc.

Golding, W. (2001). Lord of the Flies. Ibadan: Spectrum Books.

Kant, I. (1985). Foundation of the Metaphysics of Moral. In J. Feinberg (Ed.), Reason and Responsibility. California: Wadsworth Pub.

Marslow, M. (2012). Contemporary Ethics. London: Charles Finbars. Mill, J. S. (1972). Utilitarianism. London: Parker, Son and Bourn.

Nicollo, M. (1974). The Prince. Florence: Gardian.

Omobowale, T. (2011). Exam Focus: Literature in English. Ibadan: University Press, Plc.

Omoregbe, J. (1998). Ethics: A Systematic and Historical Study. Lagos: JERP.

Onigbinde, A. (1996). Human Exploration. Ibadan: Hope Publishers. Peschke, K.H. (2001). Christian Ethics (1). Bangalore: St. Paul's Press. Rawl, J. (1972). A Theory of Justice. Harvard: Harvard University Press.

Richard, M. (2012). Philosophy and Morality. Monila: Catholic Press. 